\section{A NEW ROMAN REPUBLICAN HOARD IN PRE-ROMAN DACIA (ROMANIA). A PRELIMINARY NOTE. THE MINTING PLACE OF A HYBRID TYPE}

\begin{abstract}
The discovery of a new hoard consisting of Roman republican denarii has led to the re-opening of an old debate on the copying/imitation phenomenon of Republican denarii in pre-Roman Dacia. A case study is presented in this study on one piece from this hoard. At first sight, the coin looks as a genuine denarius, but at a closer look reveals not only that the piece is a hybrid but also that between the two prototypes of obverse and reverse was a period of 25 years. Despite the widespread phenomenon of copying Roman republican denarii in pre-Roman Dacia, the metal analyses of this coin revealed the absence of the lead $(\mathrm{Pb})$ from its composition. A metal that is always present in the other cases of copies or imitations of Roman republican denarii found in Dacia.
\end{abstract}

Keywords: Republican hoard, faithful copy, pre-Roman Dacia, copying phenomenon.

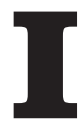

n 2018, following a metal detecting survey, a hoard was discovered in the area of the Peștiș village, Bihor County, Romania (map 1) ${ }^{1}$. The hoard consists of 379 denarii of Republican types ending with early issues of Augustus (19-4 BC). ${ }^{2}$ During the study of the coins belonging to this hoard, we came across some pieces that drew our attention as having particular features: barbarous imitations, incuses, miss-striking piece.

The subject of this short study is one coin of which obverse and reverse depictions, raises the question on the time and place when and where this coin was minted.

\footnotetext{
Denomination: denarius

Axis: 6; D: $20 \times 18 \mathrm{~mm}$; W: $3.20 \mathrm{~g}$.

Mint: uncertain

Dating: $42 \mathrm{BC} /$ post

Obverse: Head of Liber right, wearing ivy-wreath. Border of dots.

One control-mark applied twice.

Reverse: MVSARVM HERCVLES

Hercules right, wearing lion-skin and playing lyre; before, club. Catalogue: RRC, 494/36 (obverse); RRC, 410/1 (reverse)
}

\footnotetext{
The hoard was discovered by Cristian Rusu and Florin Avram.

${ }^{2} \mathrm{~A}$ monograph of this hoard is work in progress by C. Găzdac and C. Ghemiș.
}

\section{Cristian GÄZDAC}

Institute of Archaeology and Art History of Cluj-Napoca cgazdac2000@yahoo.co.uk

\section{Călin GHEMIȘ}

"Țării Crișurilor" Museum Oradea

ereshu@yahoo.com

\section{Lucian BARBU-TUDORAN}

Babes-Bolyai University, Cluj-Napoca,

Faculty of Biology and Geology

lucianbarbu@yahoo.com

DOI: $10.14795 /$ j.v7i3.550

ISSN 2360 - 266X

ISSN-L 2360 - 266X 


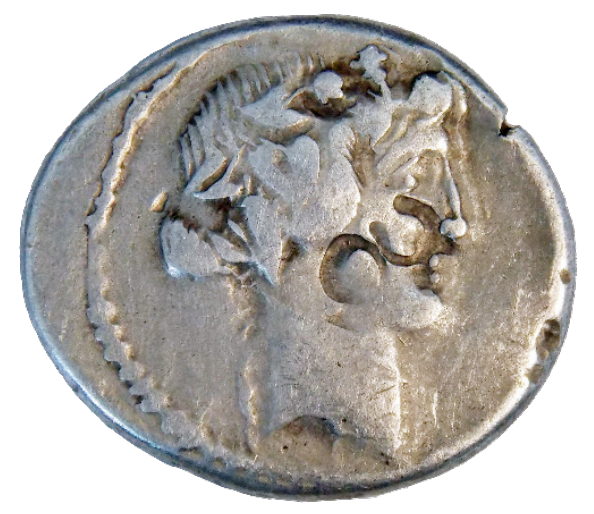

While the obverse is attributed to the moneyer C(aius) Vibius Varus, the reverse belongs to another one, Q. Pomponius Musa.

At the first sight it looks like another hybrid coin types where the person in charge with striking mixed the coin-dies.

However, it must be mentioned here that the reverse prototype was minted in $66 \mathrm{BC}$ while the obverse came out in $42 \mathrm{BC}$, thus, 25 years later!

A possible hypothesis can be that the coin under

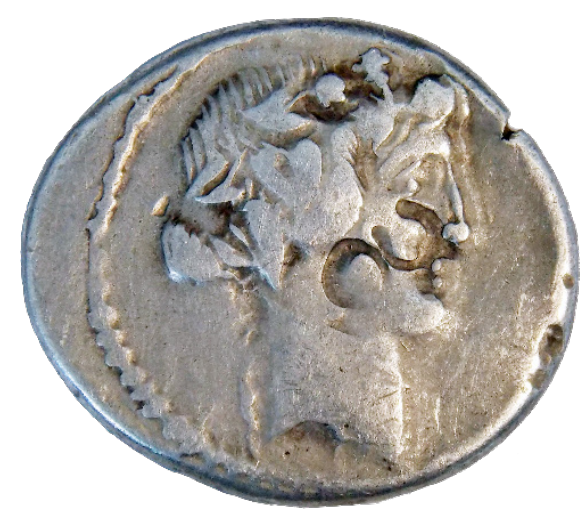

Figure 1. The obverse of the denarius under study. An imitation based on RRC 494/36 obverse prototype?

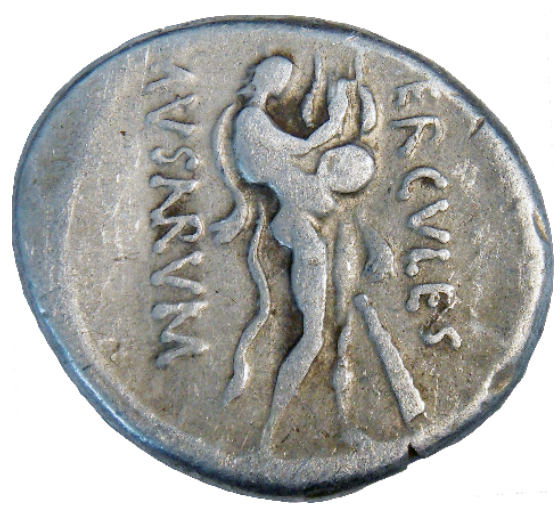

Figure 3. The obverse of the denarius under study. An imitation based on RRC 494/36 obverse prototype?

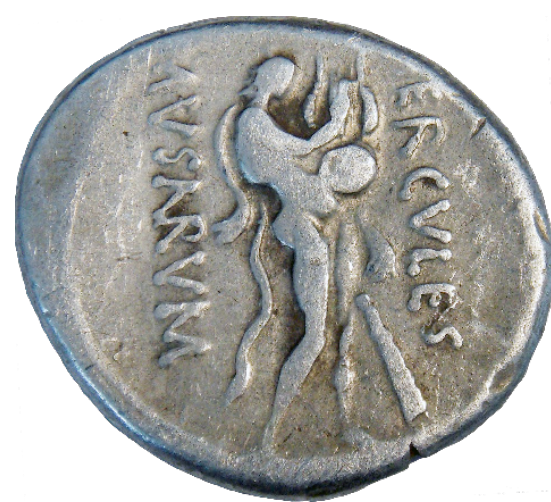

study is an imitation, which would explain the possibility of combination of those obverse and reverse which genuine prototypes were issued at such a big-time difference.

If one compares the obverse and reverse of this coin with pieces that were struck with genuine prototypes may see some quality differences (figs 4-5).

Certainly, the period of circulation can be a reason for the design looking worn out. However, the analysis of surviving features still suggests a lower quality design for the coin under study.

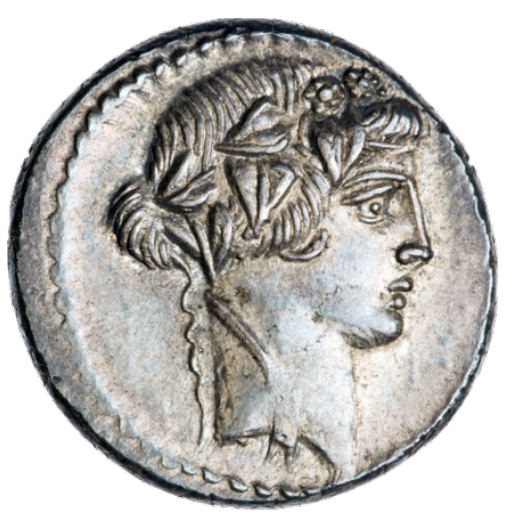

Figure 2. Genuine obverse of RRC 494/36, American Numismatic Society 1937.158.316, http://numismatics.org/ collection/1937.158.316 (accessed on September 2, 2020).

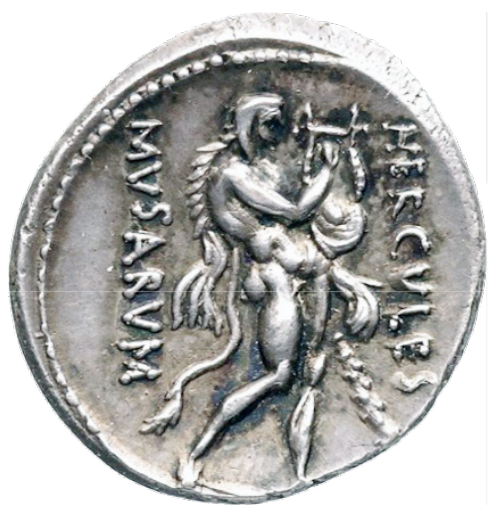

Figure 4. Genuine reverse of RRC 410/1, American Numismatic Society 1937.158.170, http://numismatics.org/ collection/1937.158.170 (accessed on September 2, 2020). 
The very same features indicate a striking method and not casting. The coin, most likely, was struck 'from dies produced mechanically by using genuine Roman coins as hubs - so-called "transfer dies". ${ }^{3}$ In pre-Roman Dacia the presence of such coin-dies is well attested. The most relevant cases are the fourteen coin-dies discovered at large hill-top settlement of Tilișca (Sibiu County) - ten derived from Republican prototypes, four were blank mistrials ${ }^{4}$ - and the three ones from the famous site of Sarmizegetusa Regia (Hunedoara County), two republicans and one imperial. ${ }^{5}$ (map 2). Both cases of coin-die finds from Dacia, indicate that the 'Dacian' coin makers were making dies from genuine denarii minted in Rome at various dates. In the case of the coin-dies from Tilișca, the 'earliest' die reproduced a prototype from $145 \mathrm{BC}$ while the 'latest' was from $72 \mathrm{BC}{ }^{6}$ The coin dies from Sarmizegetusa Regia have a chronological frame of prototypes from 126 BC to AD 14-37.

Such a piece can be included in the category of the so-called 'monetary copies'8/'faithful "copies", barely distinguishable from their Republican prototypes'.

For the territory of pre-Roman Dacia, the presence of such an imitation is not an isolated case. On the contrary, as it has been demonstrated for decades, Dacia represents a specific phenomenon of both high number of Republican hoards of mixed genuine and copied/imitated denarii. ${ }^{10}$ Hoards such as Breaza (Prahova County), ${ }^{11}$ Poroschia (Teleorman County), ${ }^{12}$ (map 2), are demonstrating that 'the copying of denarii seems to have been remarkably prevalent and widespread ${ }^{13}$ in pre-Roman Dacia.

In connection with the coin under study, it must be mentioned here that in the case of Poroschia hoard, among the 'faithful copies' were noticed those of Q. Pomponius Musa (RRC, 410/1). ${ }^{14}$

Is this hybrid 'faithful copy' produced in one of the Dacian coin workshops that have issued so many copies and imitations, both casting and striking techniques?

Non-destructive metallographic analyses were carried out.

The Nano-analysis of internal elemental mapping using a scanning electron microscope (SEM) was combined with energy dispersive X-ray spectroscopy (EDS) for each of the elements identified on the target area. The surface analysis confirmed that the exterior consists silver with some contaminates (Ag 96.1\%, Au 1.0\%, Cu 0.5\% etc.) (Fig. 1).

After surface testing, the minute cracks on the surface edge - 'deep' enough to allow elemental analysis of the internal coin flan - were examined, as well. The inner

\footnotetext{
WOYTEK et alii 2012; 137. For a detailed technique description, STANNARD 2011, 72-73

${ }^{4}$ LUPU 1989; DAVIS 2006, 323; LOCKYEAR 2008, 155.

GLODARIU/IAROSLAVSCHI/RUSU 1992, 57-68, also mentioning other coin-dies finds from pre-Roman Dacia, 63; DAVIS 2006, 322, note 4; LOCKYEAR 2008, 155.

${ }^{6}$ GLODARIU/IAROSLAVSCHI/RUSU 1992, 63.

7 GLODARIU/IAROSLAVSCHI/RUSU 1992, 62.

8 CHITESCU 1981, 47-48; DAVIS 2006, 326; WOYTEK et alii 2012; 137.

9 CARBONE 2020.

${ }_{10}$ Most recent STAN 2014, 44-67.

11 POENARU BORDEA/ȘTIRBU 1971, 265-282.

12 CHITTESCU 1965, 169-175; CHITESCU 1980, 53-70.

13 LOCKYEAR 2008, 169.

14 LOCKYEAR 2008, 157
}

portion of the coin also revealed an almost pure silver inner part of the coin (Ag 81.6\%, Au 1.9\%, Si 0.6\% etc.) (Fig. 2).

At the same time, the metal analyses indicate that the coin was actually contaminated with lot of soil elements e.g. silica (Fig. 3) -, an aspect confirmed by the finders.

At first sight a comparison with the results of similar metal analyses targeting copies/imitation of Roman republican denarii found in hoard from Dacia, e.g. Breaza and Poroschia and single cases, may suggest a common pattern: the predominance of silver followed by copper and gold.

However, there is one element, the lead $(\mathrm{Pb})$, that seems it make the difference. ${ }^{15}$ All analysed samples from the Dacian hoards and single finds have this metal in their composition but it is missing in the coin under study.

Despite the widespread phenomenon of copying Roman republican denarii in Dacia prior to Trajan, the possibility that copies could have been produced in other regions than Dacia and found in hoards from pre-Roman Dacia cannot be totally excluded.

The stylistic and metal analyses of the other coins from the Peștis hoard and other similar hoards from Romania - ending with earlier issues of Augustus - may bring more information on this aspect.

\section{REFERENCES}

\section{CARBONE 2020}

Carbone, L., Geto-Dacian imitations of Roman republican denarii: Proto-Dacian state or slave trade?, American Numismatic Society Blog, http://numismatics.org/ pocketchange/dacia/ (accessed on September 3, 2020).

\section{CHIT,ESCU 1965}

Chițescu, M., Notă asupra tezaurului de monede romane republicane de la Poroschia (r. Alexandria), Studii și Cercetări de Istorie Veche 16/1, 169-175.

\section{CHIT,ESCU 1981}

Chițescu, M., Tezaurul de la Poroschia (jud. Teleorman) și unele probleme privind monedele geto-dacice de tip republican, Studii și cercetări de numismatică 7, 53-70.

\section{CHITESCU 1981}

Chițescu, M., Numismatic aspects of the history of the Dacian State. The Roman republican coinage in Dacia and GetoDacian coins of Roman type [British Archaeological Reports International Series 112] (Oxford: B.A.R.).

\section{DAVIS 2006}

Davis, Ph., Dacian imitations of Roman Republican denarii, Apulum 43, 321-356.

\section{GLODARIU/IAROSLAVSCHI/RUSU 1992}

Glodariu, I./Iaroslavschi, E./Rusu, A., Die Munzstätte von Sarmizegetusa Regia, Ephemeris Napocensis 2, 57-68.

\section{LOCKYEAR 2008}

Lockyear, K., Aspects of Roman Republican Coins Found in Late Iron Age Dacia. In: Spinei, V./Munteanu, L. (eds.), Miscellanea numismatica antiquitatis. In honorem septagenarii magistri Virgilii Mihailescu-Bîrliba oblata, 147-176. (București: Editura Acdemiei Române).

\section{LUPU 1989}

Lupu, N., Tilișca. Așezările arheologice de pe Cățănaș (București: Editura Științifică și Enciclopedică).

\section{POENARU BORDEA/STIRBU 1971}

Poenaru Bordea, Gh./Știrbu, C., Tezaurul de denari romani republicani și de la începutul principatului descoperit la

\footnotetext{
${ }^{15}$ LOCKYEAR 2008, 162-168; WOYTEK et alii 2012; 141-156.
} 
Breaza, comuna Lisa (jud. Brașov ), Studii și Cercetări de Numismatică 5, 265-282.

$\mathrm{RRC}$

Crawford, M.H., Roman Republican Coinage (Cambridge 1974: University Press).

STAN 2014

Stan, M.G., The phenomenon of Roman republican coinage in pre-Roman Dacia. A rexamination of the evidence, Journal of Ancient History and Archaeology 1/4, 44-67. DOI: $\underline{10.14795 / j . v 1 i 4.90}$

\section{STANNARD 2011}

Stannard, C., Evaluating the monetary supply: Were dies reproduced mechanically in antiquity? In: de Callatay, F. (ed.), Quantifying monetary supplies in Greco-Roman times [Pragmateiai 19], 59-79. (Bari: Edipuglia).

WOYTEK et alii 2012

Woytek, B.E./Rodrigues, M./Cappa, F./Schreiner, M./ Radtke, M./Reinholz, U., Imitations of Roman Republican Denarii: New Metallurgical Data, American Journal of Numismatics 24, 133-162. 

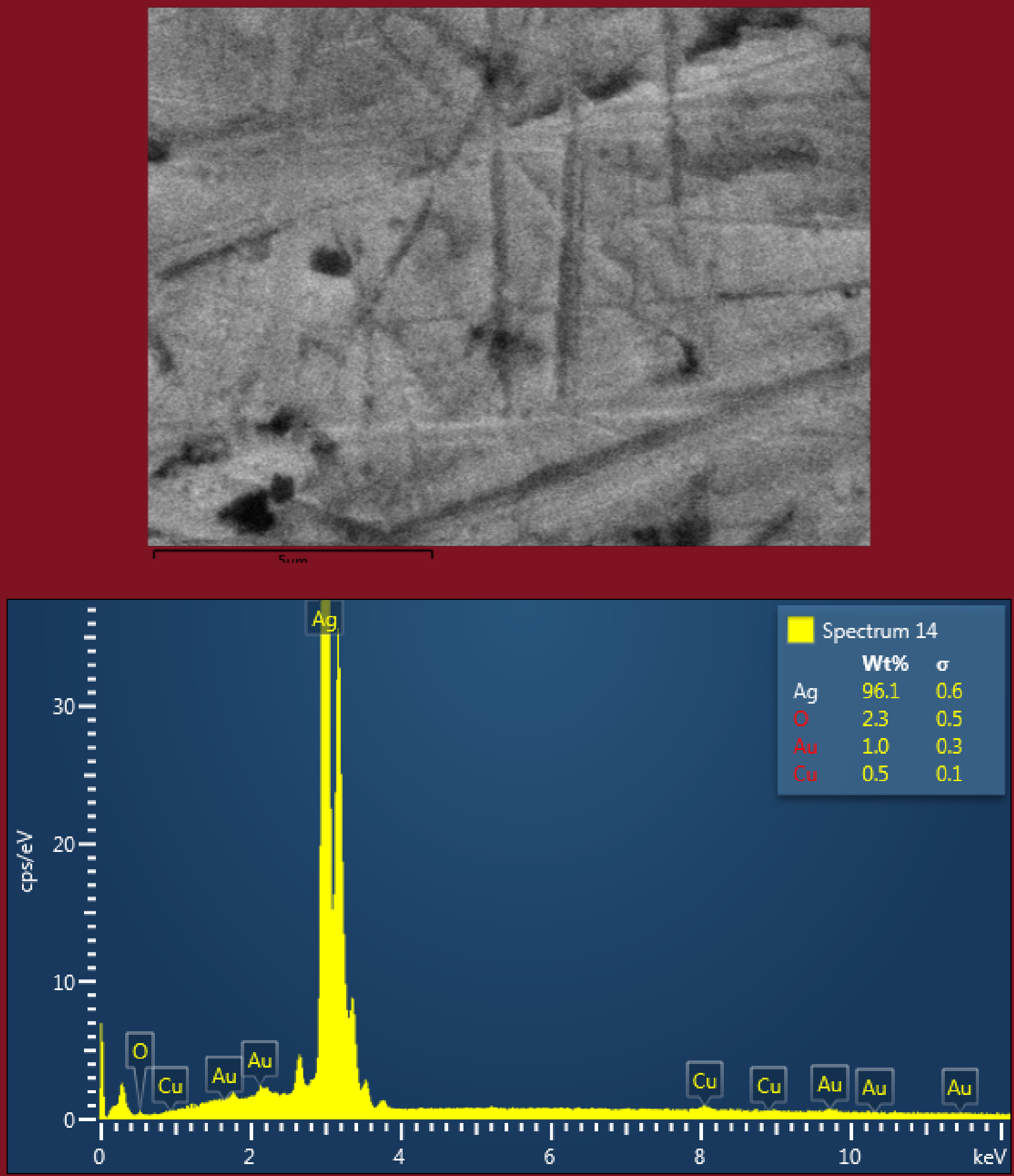

Fig. 1. SEM-EDS analysis, surface

42 Journal of Ancient History and Archaeology No.7.3/2020 

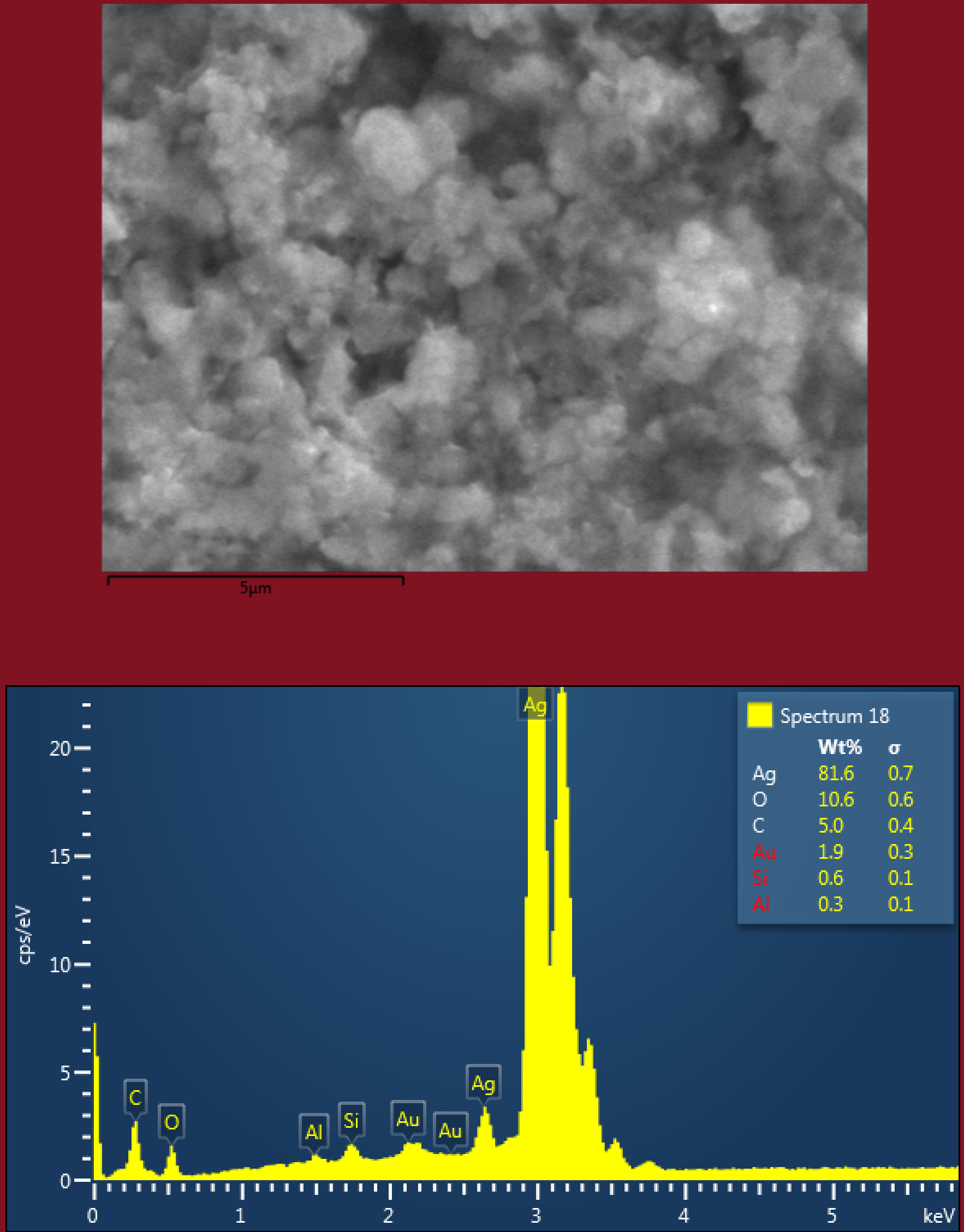

Fig. 2. SEM-EDS analysis, crack 


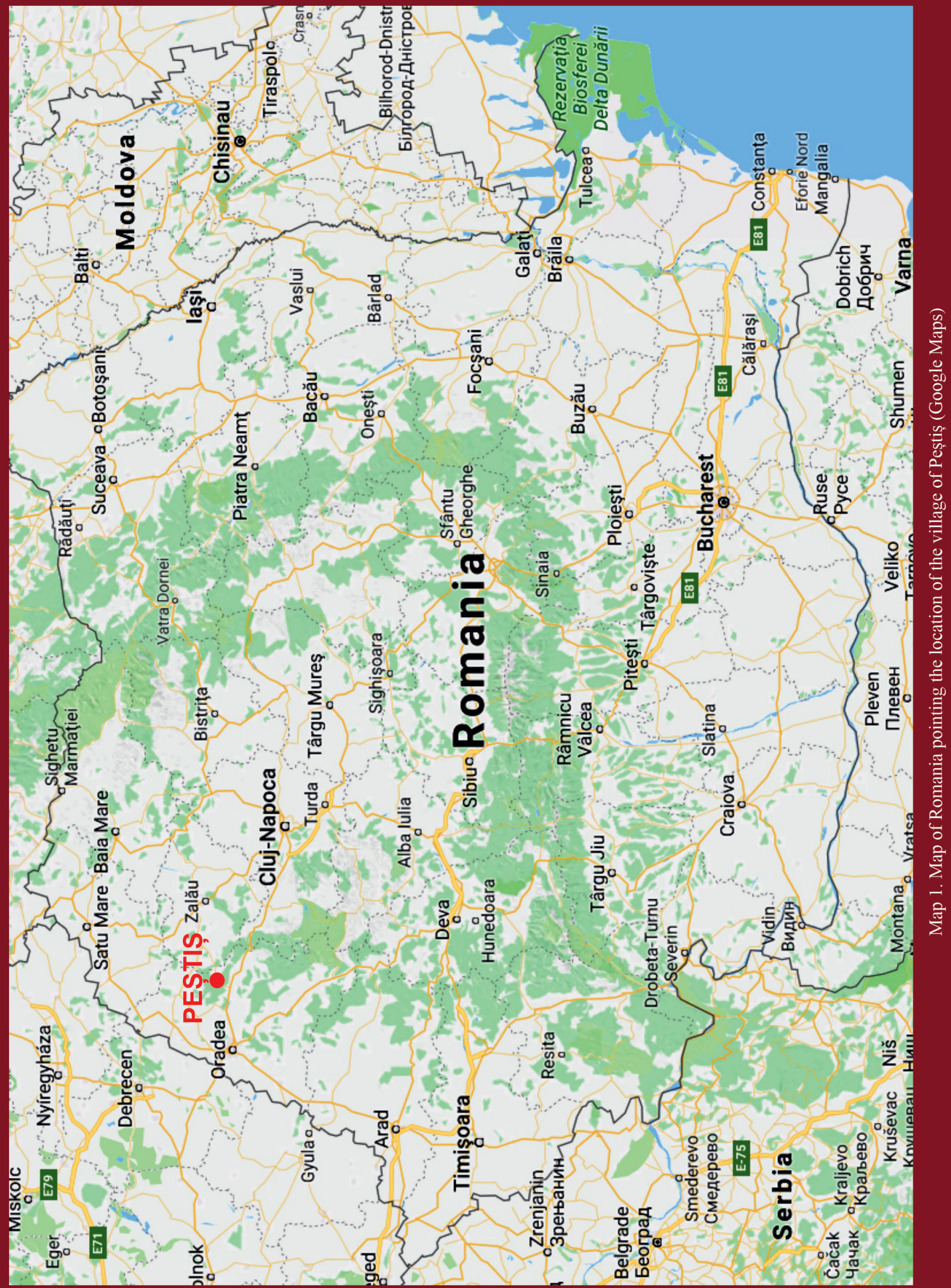




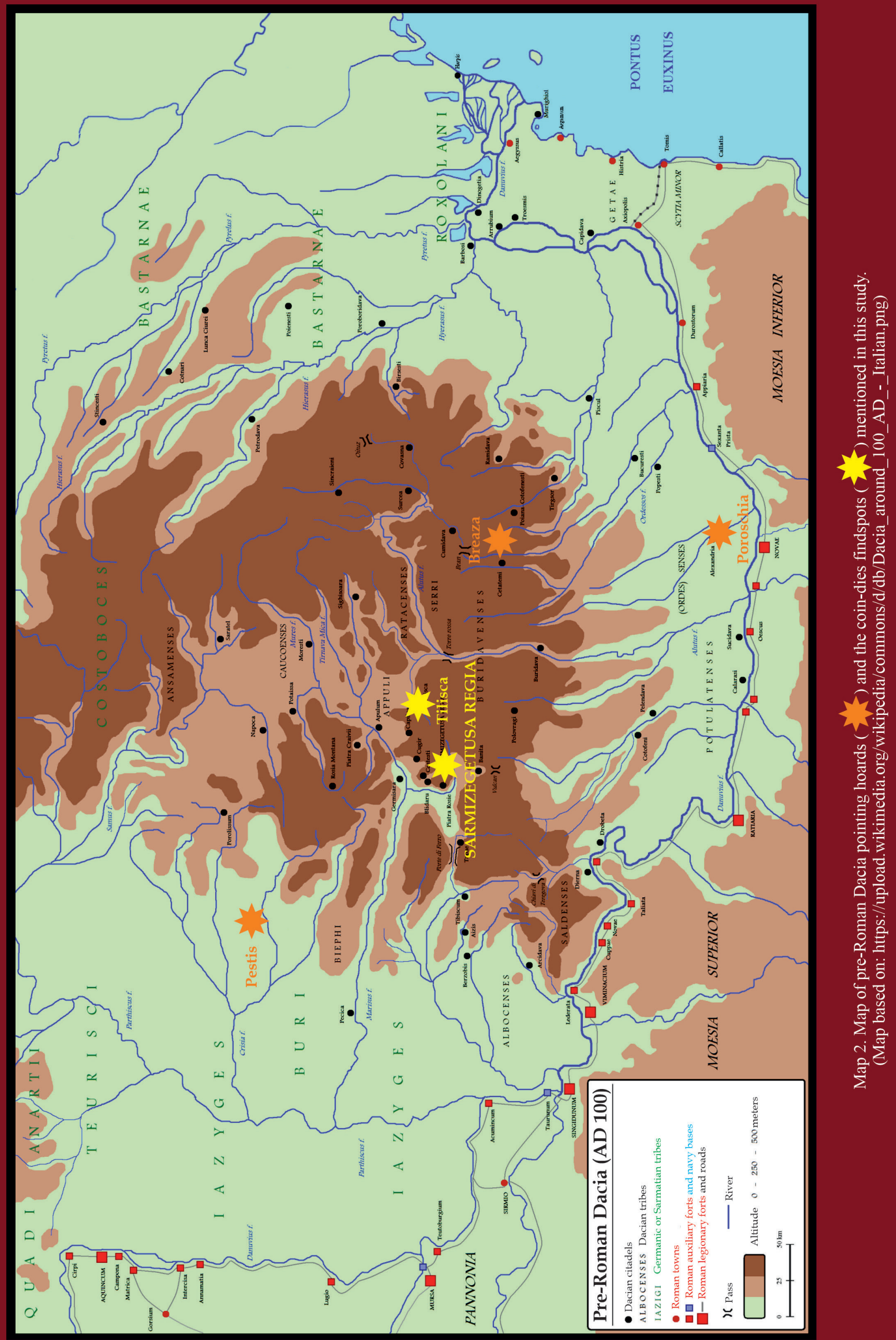

